\title{
HEPATITIS E VIRUS ANTIBODIES IN SWINE HERDS OF MATO GROSSO STATE, CENTRAL BRAZIL
}

\author{
Flávio R. Guimarães ${ }^{1}$; Thelma M. Saddi' ${ }^{1}$ Cláudia Lamarca Vitral ${ }^{2,3}$; Marcelo A. Pinto ${ }^{2}$; Ana Maria C. Gaspar²; \\ Francisco José D. Souto ${ }^{4 *}$
}

${ }^{1}$ Faculdade de Agronomia e Medicina Veterinária, Universidade Federal de Mato Grosso, Cuiabá, MT, Brasil; ${ }^{2}$ Departamento de Virologia, Instituto Oswaldo Cruz-Fiocruz, Rio de Janeiro, RJ, Brasil; ${ }^{3}$ Departamento de Microbiologia e Parasitologia, Instituto Biomédico, Universidade Federal Fluminense, Niterói, RJ, Brasil; ${ }^{4}$ Núcleo de Doenças Infecciosas e Tropicais de Mato Grosso, Faculdade de Ciências Médicas, Universidade Federal de Mato Grosso, Cuiabá, MT, Brasil

Submitted: March 30, 2005; Returned to authors for corrections: July 25, 2005; Approved: September 09, 2005

\begin{abstract}
There is no information about evidence of hepatitis $\mathrm{E}$ virus (HEV) infection in swines in Central Brazil. In order to assess if HEV circulates in swines of the State of Mato Grosso, Central Brazil, a seroprevalence study was conducted including pigs from 17 farms, corresponding to 13 counties. The animals were randomly chosen among pigs arriving to two slaughterhouses between December 2002 and February 2003. Serum samples were collected and tested for IgG antibodies against HEV (anti-HEV) by enzyme immunoassay (EIA). This EIA uses two HEV recombinant proteins as antigens, a mosaic protein (MP-II) and a protein containing region $452-617$ of the ORF2 of the HEV Burma strain as coating antigens. 211 out of 260 pigs $(81.2 \%$; $95 \mathrm{CI}=75.7 \%$, $85.6 \%$ ) were anti-HEV reactive. The seropositivity did not vary with gender or age, but ranges from $15 \%$ to $100 \%$ among the farms. Our results point out that HEV seems to circulate among pigs in Mato Grosso State, suggesting that this virus is spread over the region, as seen in other countries worldwide.
\end{abstract}

Key words: hepatitis E virus antibodies, swine, Mato Grosso State

\section{INTRODUCTION}

Hepatitis E virus (HEV) is a major cause of enterically transmitted non-A, non-B (NANB) hepatitis. It is mainly transmitted through contamination of drinking water. Consequently, outbreaks and acute sporadic cases have occurred predominantly in developing countries of tropical and subtropical areas (20). In developed countries, HEV infection is generally restricted to persons who travel to an endemic area. However, an unexpected elevated prevalence of antibodies against HEV (anti-HEV) has been reported in several populations of western countries, where hepatitis $\mathrm{E}$ is virtually never diagnosed. Most of these anti-HEV positive subjects did not have a history of travel to endemic areas. A possible explanation may be that these individuals contracted subclinical infection from an animal reservoir (9). In fact several domestic and wild animal species are infected by HEV or closed related agents (5). Among them, pigs have been largely studied as a HEV reservoir with potential zoonotic implication to human beings. HEV has been detected in pigs from several countries and anti-HEV can be shown in more than $80 \%$ of swines older than three months in some areas $(6,9,20)$. Moreover, the detection of seropositive HEV pigs in non-endemic areas suggests that an animal reservoir for HEV may exist even in countries where human infection is virtually unknown $(2,5,6,13)$. The swine HEV has been identified and characterized (9), showing to be antigenically and genetically closely related to the human HEV. Hence, infection of swine by human HEV has already been shown in experimental setting $(3,8)$. It has been also demonstrated that swine HEV can cross species barriers and

*Corresponding Author. Mailing address: Universidade Federal de Mato Grosso. Av. Fernando Corrêa, S/N. Faculdade de Ciências Médicas. CCBS1, $2^{\circ}$ piso. 78060-900, Cuiabá, MT, Brasil. Telefax: (+5565) 3615-8863, E-mail: fsouto@terra.com.br 
infect nonhuman primates, suggesting that human infection could supervene from the same route (7). In the last few years, novel strains of human HEV have been recovered from patients with acute hepatitis E in North America, Europe, and Asia $(4,13,21)$. Interestingly, these HEV strains share higher genetic identity with local swine HEV strains than with other human HEV isolates worldwide, reinforcing the hypothesis of zoonotic transmission $(18,20)$.

In South America, a non-endemic region, HEV RNA was detected in two cases of sporadic NANB hepatitis in Argentina (15). In Brazil, studies on HEV were limited to prevalence of anti-HEV antibodies in general population or specific groups in the 90 's, ranging from $0.7 \%$ to $11 \%(1,11,12,14,16,17)$. Data about the possibility of HEV circulation among animal species are still scarce in Brazil. Nonetheless, high anti-HEV prevalence among swine herds from the southeast of Brazil was recently reported (19). Aiming to investigate if HEV circulates among swines in Mato Grosso State, Central Brazil, we performed a cross-sectional survey in pigs from different counties of this region. Mato Grosso is the eighth largest pigs producer among the 27 Brazilian states and its production is progressively growing. Brazil is the fourth largest producer and exporter of pork in the world.

\section{MATERIALS AND METHODS}

\section{Serum samples}

Serum samples were collected from swines in two slaughterhouses in Varzea Grande city between December 2002 and February 2003. These establishments receive pigs from several regions of Mato Grosso regularly. Animals from thirteen counties, corresponding to seventeen different farms, arrived to both slaughterhouses during this period. At inspection, there was no animal with jaundice or liver features among herds included in this study. A total of 260 pigs aged 20 to 30 weeks (mean $=28$ weeks) were randomly chosen, 20 from each county. In order to increase the chance of detecting anti-HEV positiveanimals, we included preferentially older individuals, verifying size and owner declared-age in the register of each animal. The sample was randomly determined after stratification by same representation of gender and each county of origin. In the process of killing, electric discharge was applied to the animal's parietal region. After that, blood was drawn from a neck vein. Serum samples were frozen at $-20^{\circ} \mathrm{C}$ and stored until transported to the Laboratory of Viral Hepatitis, Department of Virology, Instituto Oswaldo Cruz (Fiocruz), Rio de Janeiro.

\section{Detection of IgG anti-HEV}

Serum samples were tested for IgG anti-HEV by EIA according to the method described previously and standardized by Obriadina et al. (10), modified by the use of anti-swine IgGhorseradish peroxidase enzyme conjugate (Sigma Chemicals St Louis MO), as described elsewhere (19). This EIA uses two
HEV recombinant proteins, a mosaic protein (MP-II) and a protein containing region 452-617 aa of the ORF2 of the HEV Burma strain as coating antigens. Briefly, microtitre wells (Nalgen Nunc International, Denmark) coated with $100 \mathrm{~mL}$ of the recombinant HEV proteins (pB166 protein 1.2-1.4 mg/mL and MPII protein 1.1-1.2 mg/mL) dissolved in the $0.5 \mathrm{M}$ carbonate buffer (CBB), pH 9.6, were incubated for $1 \mathrm{~h}$ at $37^{\circ} \mathrm{C}$ with $200 \mathrm{~mL}$ of $1 \%$ nonfat milk in CBB. Specimens were diluted $1 / 20$ in PBS with $0.05 \%$ Tween 20 containing 5\% normal goat serum (NGS), and $1 \%$ nonfat milk and incubated at $37^{\circ} \mathrm{C}$ for $30 \mathrm{~min}$. After extensive washing, a volume of $100 \mathrm{~mL}$ of horseradish peroxidase labeled anti-swine species IgG or anti-human IgG (Sigma) appropriately diluted in PBST with 5\% NGS and 1\% nonfat milk was added to each well. The wells were incubated for $30 \mathrm{~min}$ at $37^{\circ} \mathrm{C}$ and washed 6 times, followed by the addition of $100 \mathrm{~mL}$ of substrate solution (tetrametylbenzidine and $\mathrm{H}_{2} \mathrm{O}_{2}$ ). After incubation for $15 \mathrm{~min}$ at room temperature in the dark, the enzyme reaction was stopped with $50 \mathrm{~mL}$ of $1 \mathrm{~N} \mathrm{H}_{2} \mathrm{SO}_{4}$. The wells were read in an EIA reader set at $450 \mathrm{~nm}$. Due to the absence of serum samples from swines known to be IgG anti-HEV negative, the cutoff value to define an initially reactive specimen was derived from the frequency distributions of optical density (OD) values obtained from 80 low reactivity IgG anti-HEV serum samples. The OD values ranged from 0.038 to 0.493 and the value of 0.830 , which was calculated as 5 standard deviation above the mean value (0.329), was used as the cutoff value. The specificity of EIA reactivity was evaluated by blocking assays. A sample was regarded as positive for $\mathrm{IgG}$ anti-HEV if a decreased to less than $30 \%$ of the original $\mathrm{A}_{450}$ value was observed after absorption with the same recombinant proteins used as antigen probe.

\section{Statistical analysis and ethical aspects}

Chi-square, confidence intervals and odds ratios were calculated using EpiInfo 6.04 (CDC, Atlanta) in order to describe prevalence and compare the frequency of positive anti-HEV between genders. A $p$ value $<0.05$ was considered statistically significant. The protocols for specimen collection and use were submitted and approved by the Animal Care Research Committee from Oswaldo Cruz Foundation, Health Ministry, RJ, Brazil.

\section{RESULTS}

Two hundred and eleven out of 260 pigs $(81.2 \%$; $95 \mathrm{CI}=$ $75.7 \%, 85.6 \%$ ) were IgG anti-HEV reactive by EIA. There was no difference of anti-HEV prevalence by gender $(\mathrm{p}=0.7)$. On the other hand, anti-HEV prevalence ranged widely over the counties and farms, from $15 \%$ to $100 \%$. Fig. 1 shows the distribution of the seroreactivity to $\mathrm{HEV}$ according to $\mathrm{OD}_{450}$ values for the several swine serum samples collected at different counties (named A to M) when tested by EIA. It could be observed that most of serum samples from E, G, H and I counties 


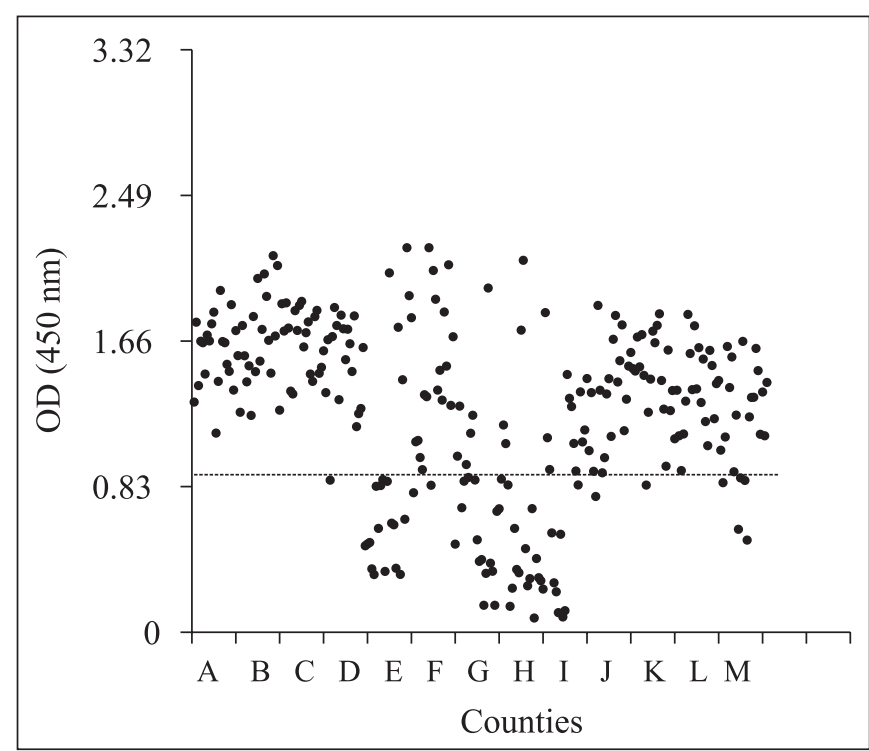

Figure 1. Levels of IgG anti-HEV reactivity in the sera of pigs from different counties (named A to M) from Mato Grosso, Central Brazil. Samples with $\mathrm{OD}_{450}$ values greater than 0.83 were considered positive.

were non-reactive to $\mathrm{HEV}$, showing $\mathrm{OD}_{450}$ values below the cutoff (0.83). On the other hand, most of serum samples from the remaining counties were highly reactive to $\mathrm{HEV}$, with OD levels ranging from 0.83 to 2.19 (mean $\mathrm{OD}_{450}$ values of 1.257 ).

\section{DISCUSSION}

To our knowledge there is no previous report on direct or indirect evidence of HEV infection in swine in Central Brazil. Our results point out that HEV may be circulating intensely among pigs in Mato Grosso State. Seventeen farms were included from thirteen different counties as far apart as $400 \mathrm{Km}$, demonstrating that the swine HEV infection is spread over the region, as seen in other countries worldwide. As a consequence of the design of the study, we do not have information about the farms in order to explain what a so wide-ranging prevalence among counties. Differences of hygienic patterns in the process of raising and handling pigs could have determined these features.

The high prevalence of antibodies to HEV identified in the present study should be interpreted with caution since we deliberately included only adult or almost adult animals with the purpose of increasing the chance of finding previously exposed animals. However, there is an agreement among the present data and others on the concept that swine HEV causes almost universal infection in pigs at least in some regions. For instance, in the southeast from Brazil, swine IgG anti-HEV was detected in $95.5 \%$ of pigs older than 20 weeks of age (19).
Evidence of infection with swine HEV was found in almost $100 \%$ of pigs older than three months of age from different USA herds (9). In herds from Australia, 92\% anti-HEV IgG prevalence was shown in pigs older than 28 weeks (2). Exposure of pigs to the $\mathrm{HEV}$ seems to occur very early as might be expected for an enteric infection in high-density farming.

An important issue raised from the discovery of swine HEV strains similar to human HEV strains is the possibility of actual zoonotic transmission from swine to humans. Swine may be a reservoir for human infection. Occasional human exposure to swine HEV strains may be accountable for asymptomatic infections and even for sporadic acute hepatitis cases occasionally seen in non-endemic areas. As a consequence, part of the anti-HEV IgG detected among blood donors in the US and other western countries may be due to HEV zoonotic transmission.

The present result indicates that humans in Central Brazil may be under risk of accidental HEV infection such as reported elsewhere $(5,6,13)$. Farming is the main economic activity of this region of Brazil and pork production has increased in last years. Consequently, local practitioners should be aware that sporadic non-A, non-B acute hepatitis cases may be due to zoonotic transmitted-HEV and this etiology should be investigated.

\section{ACKNOWLEDGEMENTS}

We thank Dr. Yuri E. Khudyakov for providing the HEV recombinant proteins. Our thanks also to the slaughterhouses Savana and Frigo-Rocha for permitting the study in their installations.

\section{RESUMO}

\section{Vírus da hepatite E em suínos no Estado de Mato Grosso, Brasil}

A infecção pelo vírus da hepatite $\mathrm{E}$ (VHE) ainda não foi detectada entre suínos na região central do Brasil. Com o intuito de avaliar se o VHE circula entre suínos no estado de Mato Grosso, um estudo de soroprevalência foi realizado em suínos de 17 propriedades rurais, correspondentes a 13 municípios. Os animais foram escolhidos aleatoriamente em lotes no momento da chegada para abate em dois frigoríficos entre dezembro de 2002 e fevereiro de 2003. Amostras de soro foram coletadas e testadas para a presença de anticorpos de classe IgG contra o VHE (anti-VHE) por ensaio imuno-enzimático (EIE). Este EIE foi executado utilizando-se duas proteínas recombinantes como antígenos. Uma proteína mosaico (MP-II) e outra proteína contendo a região dos aminoácidos 452 a 617 da ORF2 da cepa Burma do VHE. 211 dos 260 animais examinados eram anti-VHE reativos. A soropositividade não variou com gênero e idade, mas variou entre $15 \%$ a $100 \%$ de uma propriedade para outra. 
Nossos resultados apontaram que o VHE parece circular entre suínos do estado de Mato Grosso, sugerindo que o vírus encontra-se disseminado na região, como verificado em outros países ao redor do mundo.

Palavras-chave: vírus da hepatite E, suínos, Estado de Mato Grosso

\section{REFERENCES}

1. Assis, S.B.; Souto, F.J.; Fontes, C.J.; Gaspar, A.M. Prevalência da infecção pelos vírus das hepatites A e E em escolares de município da Amazônia mato-grossense. Rev. Soc. Bras. Med. Trop., 35, 155$158,2002$.

2. Chandler, J.D.; Riddell, M.A.; Li, F.; Love, R.J.; Anderson, D.A. Serological evidence for swine hepatitis E virus infection in Australian pig herds. Vet. Microbiol., 68, 95-105, 1999.

3. Halbur, P.G.; Kasorndorkbua, C.; Gilbert, C.; Guenette, D.; Potters, M.B.; Purcell, R.H.; Emerson, S.U.; Toth, T.E.; Meng, X.J. Comparative pathogenesis of infection of pigs with hepatitis $\mathrm{E}$ viruses recovered from a pig and a human. J. Clin. Microbiol., 39 (3), 91823, 2001.

4. Kwo, P.Y.; Schlauder, G.G.; Carpenter, H.A.; Murphy. P.J.; Rosenblatt, J.E.; Dawson, G.J.; Mast, E.E.; Krawczynski, K.; Balan, V. Acute hepatitis E by a new isolate acquired in the United States. Mayo Clin. Proc., 72, 1133-1136, 1997.

5. Meng, X.J. Novel strains of hepatitis E virus identified from humans and other animal species: is hepatitis E a zoonosis? J. Hepatol., 33, 842-845, 2000.

6. Meng, X.J.; Dea, S.; Engle, R.E.; Friendship, R.; Lyoo, Y.S.; Sirinarumitr, T.; Urairong, K.; Wang, D.; Wong, D.; Yoo, D.; Zhang, Y.; Purcell, R.H.; Emerson, S.U. Prevalence of antibodies to the hepatitis $\mathrm{E}$ virus in pigs from countries where hepatitis $\mathrm{E}$ is common or is rare in the human population. J. Med. Virol., 59, 297-302, 1999.

7. Meng, X.J.; Halbur, P.G.; Haynes, J.S.; Tsavera, T.S.; Bruna, J.D.; Royer, R.L.; Purcell, R.H.; Emerson, S.U. Experimental infection of pigs with the newly identified swine hepatitis E virus (swine HEV), but not with human strains of HEV. Arch. Virol., 143, 1405-1415, 1998.

8. Meng, X.J.; Halbur, P.G.; Shapiro, M.S.; Govindarajan, S.; Bruna, J.D.; Mushahwar, I.K.; Purcell, R.H.; Emerson, S.U. Genetic and experimental evidence for cross-species infection by swine hepatitis E virus. J. Virol., 12 (12), 1244-1247, 1998b.

9. Meng, X.J.; Purcell, R.H.; Halbur, P.G.; Lehman, J.R.; Webb, D.M.; Tsareva, T.S.; Haynes, J.S.; Thacker, B.J.; Emerson, S.U. A novel virus in swine is closely related to the human hepatitis E virus. Proc. Natl. Acad. Sci., 94, 9860-9865, 1997.

10. Obriadina, A.; Meng, J.; Ulanova, T.; Trinta, K.; Burkov, A.; Fields, H.; Khudyakov, Y. A new enzyme immunoassay for the detection of antibody to hepatitis E virus. J. Gastroenterol. Hepatol., 17, S360S364, 2002.

11. Pang, L.; Alencar, F.E.C.; Cerutti-Jr, C.; Milhous, W.K.; Andrade, A.L.; Oliveira, R.; Kanesa-Thasan, N.; MaCarthy, P.O.; Hoke-Jr, C.H. Hepatitis E infection in the Brazilian Amazon. Am. J. Trop. Med. Hyg., 52, 347-348, 1995.

12. Parana, R.; Cotrim, H.P.; Cortey-Boennec, M.L.; Trepo, C.; Lyra, L.G. Prevalence of hepatitis $\mathrm{E}$ virus $\mathrm{IgG}$ antibodies in patients from a referral unit of liver diseases in Salvador, Bahia, Brazil. Am. J. Trop. Med. Hyg., 57, 60-61, 1997.

13. Pina, S.; Buti, M.; Cotrina, M.; Piella, J.; Girones, R. HEV identified in serum from humans with acute hepatitis and in sewage of animal origin in Spain. J. Hepatol., 33, 826-833, 2000.

14. Santos, D.C.; Souto, F.J.; Santos, D.R.; Vitral, C.L.; Gaspar, A.M. Seroepidemiological markers of enterically transmitted viral hepatitis $\mathrm{A}$ and $\mathrm{E}$ in individuals living in a community located in the North Area of Rio de Janeiro, RJ, Brazil. Mem. Inst. Oswaldo Cruz, 97, 637-640, 2002.

15. Schlauder, G.G.; Frider, B.; Sookoyan, S.; Castano, G.C.; Mushawar, I.K. Identification of two novel isolates E virus in Argentina. $J$. Infect. Dis., 182, 294-297, 2000.

16. Souto, F.J.; Fontes, C.J. Prevalence of IgG-class antibodies against hepatitis E vírus in a community of the Southern Amazon: a randomized survey. Ann. Trop. Med. Parasitol., 92, 623-625, 1998.

17. Trinta, K.S.; Liberto, M.I.; de Paula, V.S.; Yoshida, C.F.; Gaspar, A.M. Hepatitis E virus infection in selected Brazilian populations. Mem. Inst. Oswaldo Cruz, 96, 25-29, 2001.

18. Van der Poel, W.H.; Verschoor, F.; van der Heide, R.; Herrera, M.I.; Vivo, A.; Kooreman, M.; Husman, A.M. Hepatitis E virus sequences in swine related to sequences in humans, the Netherlands. Emerg. Infect. Dis., 7, 970-976, 2001.

19. Vitral, C.L.; Pinto, M.A.; Lewis-Ximenes, L.L.; Khudyakov, Y.E.; dos Santos, D.R.; Gaspar, A.M.C. Serological evidence of hepatitis E virus infection in different animal species from the southeast of Brazil. Mem. Inst. Oswaldo Cruz, 100, 117-122, 2005.

20. Wu, J.C.; Chen, C.M.; Chiang, T.Y.; Sheen, I.J.; Chen, J.Y.; Tsai, W.S.; Huang, Y.H.; Lee, S.D. Clinical and epidemiological implications of swine hepatitis E virus infection. J. Med. Virol., 60, 166-171, 2000.

21. Wu, J.C.; Sheen, I.J.; Chiang, T.Y.; Sheng, W.Y.; Wang, Y.J.; Chan, C.Y.; Lee, S.D. The impact of travelling to endemic area on the spread of hepatits $\mathrm{E}$ virus infection: epidemiological and molecular analyses. Hepatology, 27,1415-1420, 1998. 